Article

\title{
Polyketide Derivatives, Guhypoxylonols A-D from a Mangrove Endophytic Fungus Aspergillus sp. GXNU-Y45 That Inhibit Nitric Oxide Production
}

\author{
Xiaoya Qin ${ }^{1}$, Jiguo Huang ${ }^{2}$, Dexiong Zhou ${ }^{1}$, Wenxiu Zhang ${ }^{1}$, Yanjun Zhang ${ }^{3}$, Jun $\mathrm{Li}^{1}{ }^{1}$, Ruiyun Yang ${ }^{1, *}$ and \\ Xishan Huang ${ }^{1, *}$ \\ 1 State Key Laboratory for Chemistry and Molecular Engineering of Medicinal Resources, Collaborative \\ Innovation Center for Guangxi Ethnic Medicine, College of Chemistry and Pharmaceutical Sciences, Guangxi \\ Normal University, Guilin 541005, China; qinxiaoya6536@163.com (X.Q.); zhoudexiong3@163.com (D.Z.); \\ wenxiuz912@163.com (W.Z.); lijun9593@gxnu.edu.cn (J.L.) \\ 2 School of Chemical Engineering and Technology, Guangdong Industry Polytechnic, Guangzhou 510300, \\ China; huangiiguo@126.com \\ 3 Guangxi Key Laboratory of Green Chemical Materials and Safety Technology, Beibu Gulf University, \\ Qinzhou 535011, China; Zhangyj201608@163.com \\ * Correspondence: yang_rui_yun@163.com (R.Y.); huangxishan13@foxmail.com (X.H.); \\ Tel.: +86-77-3212-0958 (X.H.)
}

check for updates

Citation: Qin, X.; Huang, J.; Zhou, D.; Zhang, W.; Zhang, Y.; Li, J.; Yang, R.; Huang, X. Polyketide Derivatives, Guhypoxylonols A-D from a Mangrove Endophytic Fungus Aspergillus sp. GXNU-Y45 That Inhibit Nitric Oxide Production. Mar. Drugs 2022, 20, 5. https://doi.org/ $10.3390 / \mathrm{md} 20010005$

Academic Editor: Anake Kijjoa

Received: 23 November 2021 Accepted: 20 December 2021 Published: 21 December 2021

Publisher's Note: MDPI stays neutral with regard to jurisdictional claims in published maps and institutional affiliations.

Copyright: (c) 2021 by the authors. Licensee MDPI, Basel, Switzerland. This article is an open access article distributed under the terms and conditions of the Creative Commons Attribution (CC BY) license (https:// creativecommons.org/licenses/by/ $4.0 /)$.

\begin{abstract}
Four undescribed compounds, guhypoxylonols A (1), B (2), C (3), and D (4), were isolated from the mangrove endophytic fungus Aspergillus sp. GXNU-Y45, together with seven previously reported metabolites. The structures of 1-4 were elucidated based on analysis of HRESIMS and NMR spectroscopic data. The absolute configurations of the stereogenic carbons in 1-3 were established through a combination of spectroscopic data and electronic circular dichroism (ECD). Compounds 1-11 were evaluated for their anti-inflammatory activity. Compounds 1, 3, 4, and 6 showed an inhibitory activity against the production of nitric oxide (NO), with the $\mathrm{IC}_{50}$ values of $14.42 \pm 0.11$, $18.03 \pm 0.14,16.66 \pm 0.21$, and $21.05 \pm 0.13 \mu \mathrm{M}$, respectively.
\end{abstract}

Keywords: Aspergillus sp.; mangrove endophytic fungus; guhypoxylonols A-D; anti-inflammatory

\section{Introduction}

Marine-derived endophytic fungi have drawn considerable attention for drug discovery, and have been shown to produce various constituents, including sesquiterpenes, alkaloids, and polyketides [1]. Fungi are prolific producers of a variety of biologically active secondary metabolites, including anti-inflammatory, antibiotics, and cytotoxic compounds [1,2]. Lately, the investigation of the constituents of a fungus Pleosporales sp., isolated from diverse marine environments has led to the discovery of broad-spectrum cytotoxic secondary metabolites, such as dipleosporalones A and B [3]. In recent years, metabolites discovered from marine-derived fungi have been shown to display a broad range of promising biological activities [1-6]. Our group has reported a series of polyketides and structurally related polyketide derivatives from the culture of mangrove endophytic fungi [7-10].

As part of our ongoing project to discover anti-inflammatory polyketide derivatives from mangrove endophytic fungi, modifications of the composition of the culture medium were employed to reinvestigate the secondary metabolites of Aspergillus sp. GXNU-Y45, isolated from a fresh branch of the mangrove plant Acanthus ilicifolius L. Chemical investigation of its culture extracts resulted in the isolation of four undescribed polyketides, guhypoxylonols A (1), B (2), C (3), and D (4), together with seven previously reported metabolites (5-11) (Figure 1). Preliminarily screening of 1-11 in Supplementary Materials for their ability to prevent NO production of lipopolysaccharide (LPS)-stimulated RAW264.7 cells showed that 1, 3, 4, and 6 have significant inhibitory potency. Herein 
we report the details of isolation, structure elucidation, and anti-inflammatory activity evaluation of $1,3,4$, and 6 .

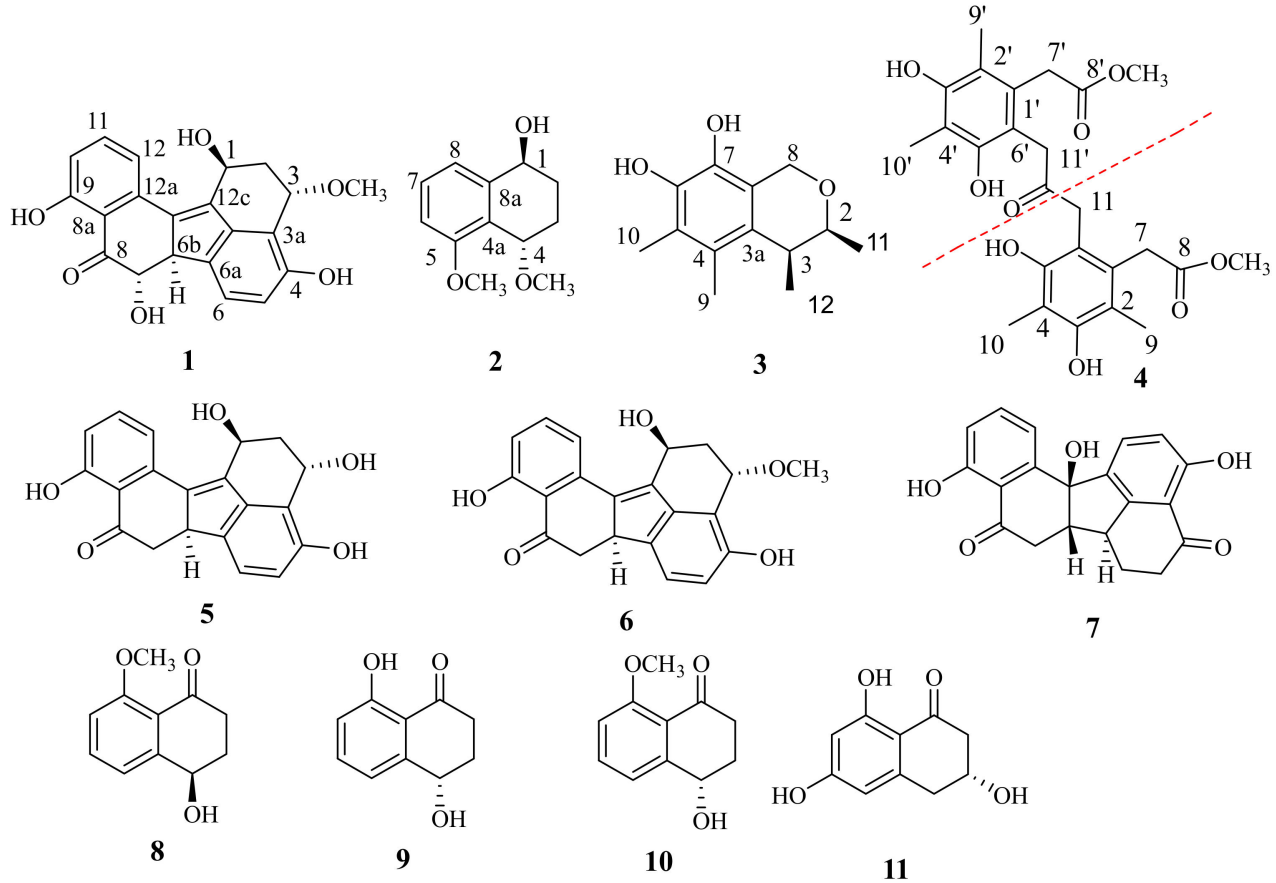

Figure 1. Structures of 1-11.

\section{Results and Discussion}

\subsection{Structure Elucidation of the Compounds}

Compound (1) was obtained as a brown oil. The molecular formula $\mathrm{C}_{21} \mathrm{H}_{18} \mathrm{O}_{6}$ was determined from the quasimolecular ion at $m / z 389.1004\left([\mathrm{M}+\mathrm{Na}]^{+}\right.$, calcd for $\mathrm{C}_{21} \mathrm{H}_{18} \mathrm{O}_{6} \mathrm{Na}$, 389.1001) from a high resolution electrospray ionization mass spectrum (HRESIMS) and the ${ }^{13} \mathrm{C}$ NMR spectrum (Table 1$)$. The ${ }^{1} \mathrm{H}$ NMR spectrum of 1 displayed two multiplets at $\delta_{\mathrm{H}} 2.50(1 \mathrm{H}, \mathrm{H}-2 \alpha)$, and $1.68(1 \mathrm{H}, \mathrm{H}-2 \beta)$, one multiplet at $\delta_{\mathrm{H}} 5.22(1 \mathrm{H}, \mathrm{H}-1)$, one triplet at $\delta_{\mathrm{H}} 4.74(1 \mathrm{H}, \mathrm{H}-3)$, two double doublets at $\delta_{\mathrm{H}} 3.94(1 \mathrm{H}, \mathrm{H}-6 \mathrm{~b})$, and $\delta_{\mathrm{H}} 3.78(1 \mathrm{H}, \mathrm{H}-7)$, five aromatic protons at $\delta_{\mathrm{H}} 6.71(1 \mathrm{H}, \mathrm{H}-5), 7.38(1 \mathrm{H}, \mathrm{H}-6), 6.84(1 \mathrm{H}, \mathrm{H}-10), 7.55(1 \mathrm{H}, \mathrm{H}-11)$, and $7.43(1 \mathrm{H}, \mathrm{H}-12)$, two phenolic hydroxyl protons at $\delta_{\mathrm{H}} 9.54(1 \mathrm{H}, \mathrm{H}-4)$, and $12.32(1 \mathrm{H}, \mathrm{H}-9)$. The ${ }^{13} \mathrm{C}$ NMR spectrum (Table 1 ) exhibited 21 carbon signals including one ketone carbonyl at $\delta_{\mathrm{C}} 206.5$, one methoxyl at $\delta_{\mathrm{C}} 55.9$, one $\mathrm{sp}^{3}$ methylene at $\delta_{\mathrm{C}} 39.7$, four oxygenated methine $\mathrm{sp}^{3}$ at $\delta_{\mathrm{C}} 76.4,70.4,62.5$, and 56.1, five protonated $\mathrm{sp}^{2}$ carbons at $\delta_{\mathrm{C}} 136.1,125.5,121.5$, 115.6, and 112.9, and eight non-protonated $\mathrm{sp}^{2}$ carbons at $\delta_{\mathrm{C}} 161.4,154.4,134.4,117.8,114.0$, $138.2,134.2,140.0$, and 144.9. Analysis of the 2D-NMR spectra (Figure 2) revealed that the structure of 1 resembled that of the previously reported 6 [11] except for the chemical shift value of $\mathrm{C}-7$ which appeared at $\delta_{\mathrm{C}} 76.4 \mathrm{CH}$, indicating that $\mathrm{C}-7$ is oxygen-bearing.

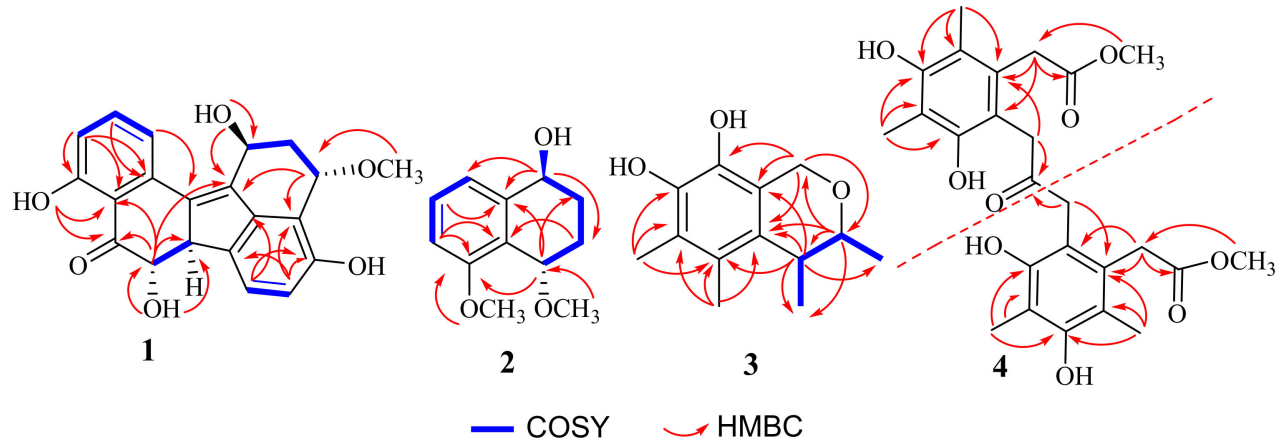

Figure 2. Key COSY of 1-3 and HMBC correlations of 1-4. 
Table $1 .{ }^{1} \mathrm{H}$ and ${ }^{13} \mathrm{C}$ NMR (DMSO- $d_{6}, 600$ and $150 \mathrm{MHz}$ ) and COSY and HMBC assignment of 1.

\begin{tabular}{|c|c|c|c|c|}
\hline Position & $\delta_{\mathrm{C}}$, Type & $\delta_{\mathrm{H}}$, (Mult., $J$ in $\mathrm{Hz}$ ) & COSY & НМВС \\
\hline 1 & $62.5, \mathrm{CH}$ & $5.22, \mathrm{~m}$ & $\mathrm{H}-2$ & \\
\hline $2 \alpha$ & & $2.50, \mathrm{~m}$ & $\mathrm{H}_{-1} 3$ & \\
\hline $2 \beta$ & $39.7, \mathrm{CH}_{2}$ & $1.68, \mathrm{~m}$ & $\mathrm{H}-1,3$ & \\
\hline 3 & $70.4, \mathrm{CH}$ & $4.74, \mathrm{t}(3.0)$ & $\mathrm{H}-2$ & $C-3 a, 12 c$ \\
\hline 4 & $154.4, \mathrm{C}$ & & & \\
\hline 5 & $112.9, \mathrm{CH}$ & $6.71, \mathrm{~d}(8.0)$ & $\mathrm{H}-6$ & $C-3 a, 4,6 a$ \\
\hline 6 & $125.5, \mathrm{CH}$ & $7.38, \mathrm{~d}(8.0)$ & $\mathrm{H}-5$ & $C-4,12 d$ \\
\hline $6 a$ & $134.4, \mathrm{C}$ & & & \\
\hline $6 b$ & $56.1, \mathrm{CH}$ & $3.94, \mathrm{dd}(12.4,3.1)$ & $\mathrm{H}-7$ & \\
\hline 7 & $76.4, \mathrm{CH}$ & 3.78, dd $(12.3,5.6)$ & $\mathrm{H}-6 \mathrm{~b}$ & $C-6 b, 8,8 a, 12 c$ \\
\hline 8 & $206.5, C$ & & & \\
\hline $8 a$ & $114.0, \mathrm{C}$ & & & \\
\hline 9 & $161.4, \mathrm{C}$ & & & \\
\hline 10 & $115.6, \mathrm{CH}$ & $6.84, \mathrm{~d}(8.2)$ & $\mathrm{H}-11$ & $C-8 a, 9,12 a$ \\
\hline 11 & 136.1, CH & $7.55, \mathrm{~d}(8.0)$ & $\mathrm{H}-10,12$ & C-12a \\
\hline 12 & $121.5, \mathrm{CH}$ & $7.43, \mathrm{~d}(7.7)$ & H-11 & $C-12 b$ \\
\hline $12 \mathrm{a}$ & $138.2, \mathrm{C}$ & & & \\
\hline $12 b$ & $134.2, \mathrm{C}$ & & & \\
\hline $12 \mathrm{c}$ & 140.0, C & & & \\
\hline $12 \mathrm{~d}$ & $144.9, \mathrm{C}$ & & & \\
\hline $1-\mathrm{OH}$ & & $5.06, \mathrm{~d}(7.8)$ & & $C-1,12 c$ \\
\hline $4-\mathrm{OH}$ & & $9.54, \mathrm{~s}$ & & \\
\hline $7-\mathrm{OH}$ & & 6.17, d (5.9) & & $C-6 b, 7$ \\
\hline 9-OH & & $12.32, \mathrm{~s}$ & & C-8, $8 \mathrm{a}$ \\
\hline $3-\mathrm{OCH}_{3}$ & $55.9, \mathrm{CH}_{3}$ & $3.29, \mathrm{~s}$ & & $C-3$ \\
\hline
\end{tabular}

The relative configuration of $\mathbf{1}$ was determined by the NOESY spectrum (Figure 3) analysis. The NOESY correlations between $\mathrm{H}-1\left(\delta_{\mathrm{H}} 5.22\right)$ and $\mathrm{OCH}_{3}-3\left(\delta_{\mathrm{H}} 3.29\right), \mathrm{OCH}_{3}-3$ and $\mathrm{H}-6 \mathrm{~b}\left(\delta_{\mathrm{H}} 3.94\right)$, and $\mathrm{H}-6 \mathrm{~b}$ and $\mathrm{OH}-7\left(\delta_{\mathrm{H}} 6.17\right)$ determined the relative configuration of 1 as $1 S^{*} 3 S^{*} 6 \mathrm{~b} R^{*} 7 S^{*}$. The experimental ECD spectrum of 1 was recorded (Figure 4) and the calculated ECD spectrum of $15356 \mathrm{~b} R 7 S-1$ fits well with the experimental ECD spectrum of $\mathbf{1}$, as shown in Figure 4 . Since $\mathbf{1}$ has not been previously reported, it was named guhypoxylonol A.
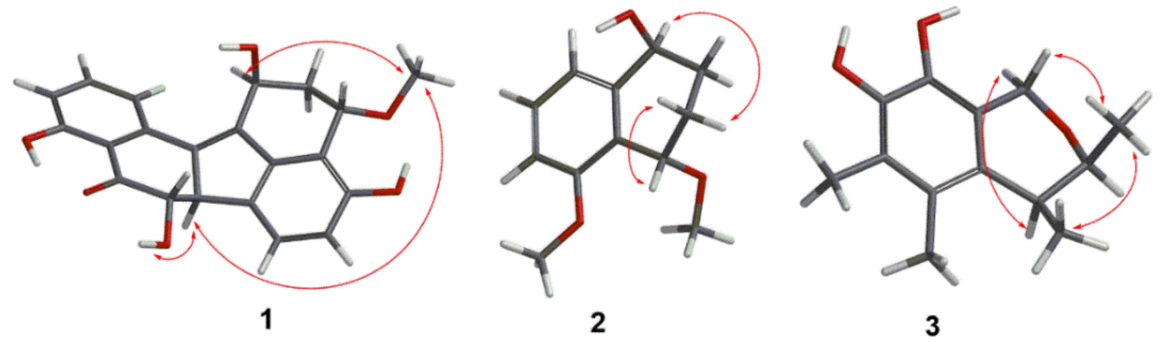

Figure 3. Key NOESY correlations in 1-3 


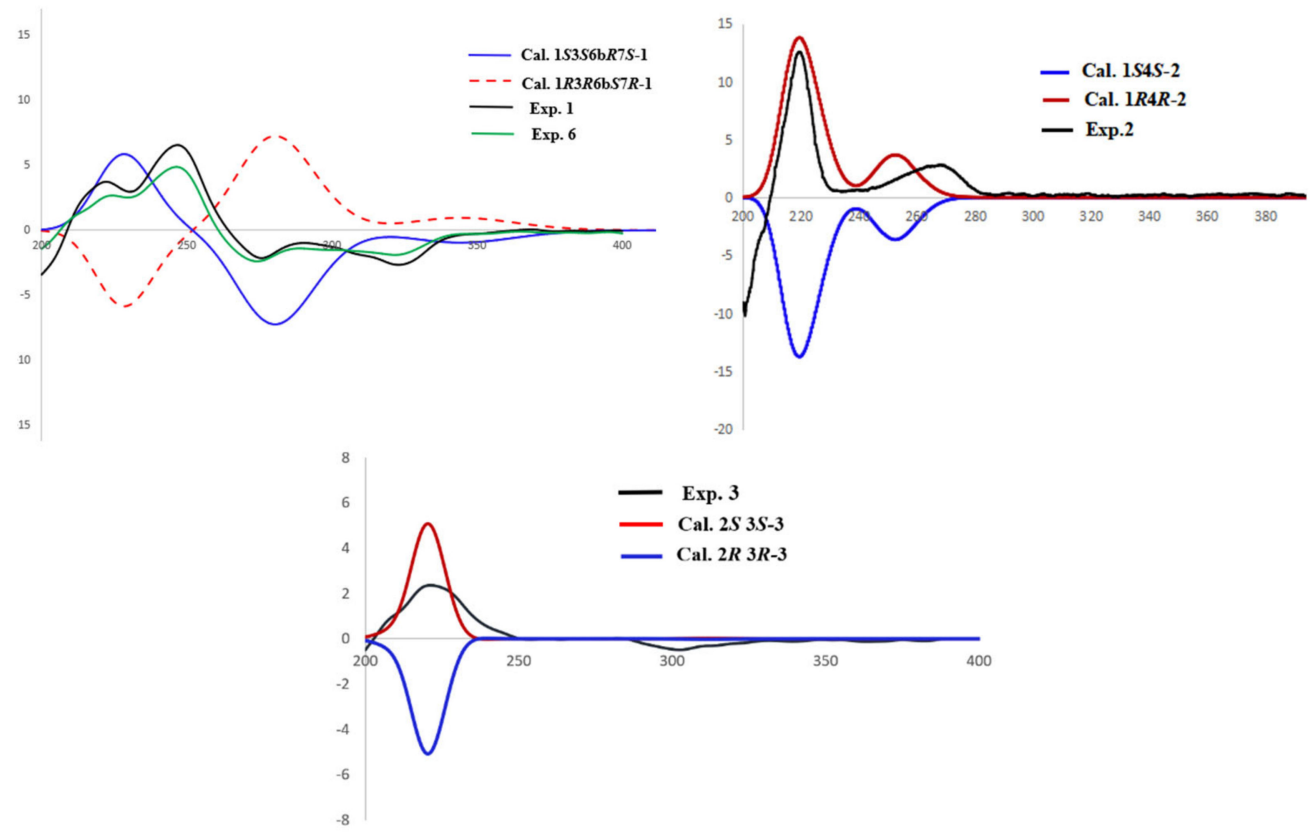

Figure 4. Experimental ECD and calculated ECD spectra of 1-3.

Compound (2) was obtained as a colorless powder with a molecular formula of $\mathrm{C}_{12} \mathrm{H}_{16} \mathrm{O}_{3}$ as deduced from the HRESIMS $\mathrm{m} / z 231.0998[\mathrm{M}+\mathrm{Na}]^{+}$(cald 231.0997 for $\mathrm{C}_{12} \mathrm{H}_{16} \mathrm{O}_{3} \mathrm{Na}$ ), indicating six degrees of unsaturation. The ${ }^{1} \mathrm{H}-\mathrm{NMR}$ (Table 2) showed two methoxyl singlets at $\delta_{\mathrm{H}} 3.31\left(3 \mathrm{H}, \mathrm{s}, \mathrm{OCH}_{3}-4\right)$, and $3.75\left(3 \mathrm{H}, \mathrm{s}, \mathrm{OCH}_{3}-5\right)$, three aromatic protons at $\delta_{\mathrm{H}} 7.24(1 \mathrm{H}, \mathrm{d}, J=7.9 \mathrm{~Hz}, \mathrm{H}-6), 7.14(1 \mathrm{H}, \mathrm{d}, J=7.7 \mathrm{~Hz}, \mathrm{H}-8)$, and $6.83(1 \mathrm{H}, \mathrm{d}$, $J=8.1 \mathrm{~Hz}, \mathrm{H}-7)$, two multiplets at $\delta_{\mathrm{H}} 1.80\left(2 \mathrm{H}, \mathrm{m}, \mathrm{CH}_{2}-2\right)$, and $1.51,2.09\left(2 \mathrm{H}, \mathrm{m}, \mathrm{CH}_{2}-3\right)$, and two multiplets at $\delta_{\mathrm{H}} 4.41(1 \mathrm{H}, \mathrm{m}, \mathrm{H}-1)$, and $4.35(1 \mathrm{H}, \mathrm{m}, \mathrm{H}-4)$. The ${ }^{13} \mathrm{C}$ NMR spectrum (Table 2) showed 12 carbon signals comprising six aromatic carbons of a benzene ring $\left(\delta_{\mathrm{C}} 157.5 \mathrm{C}, 143.1 \mathrm{C}, 128.5 \mathrm{CH}, 124.8 \mathrm{C}, 118.7 \mathrm{CH}\right.$ and $\left.108.8 \mathrm{CH}\right)$, two methoxyls $\left(\delta_{\mathrm{C}} 55.7\right.$ and 56.7), two methylene $\mathrm{sp}^{3}\left(\delta_{\mathrm{C}} 27.2\right.$ and 24.7$)$, and two oxygenated methine $\mathrm{sp}^{3}\left(\delta_{\mathrm{C}} 69.8\right.$ and 67.8). The COSY spectrum (Table 2) of 2 displayed two isolated proton spin systems $\left(\mathrm{H}-1 / \mathrm{H}_{2}-2 / \mathrm{H}_{2}-3 / \mathrm{H}-4\right.$, and $\left.\mathrm{H}-6 / \mathrm{H}-7 / \mathrm{H}-8\right)$. The HMBC spectrum showed correlations from the proton sinal at $\delta_{\mathrm{H}} 4.41(1 \mathrm{H}, \mathrm{m}, \mathrm{H}-1)$ to $\delta_{\mathrm{C}} 24.7(\mathrm{C}-3), 118.7(\mathrm{C}-8)$, and $143.1(\mathrm{C}-8 \mathrm{a})$, from $\delta_{\mathrm{H}} 4.35(1 \mathrm{H}, \mathrm{t}, J=2.8 \mathrm{~Hz}, \mathrm{H}-4)$ to $\delta_{\mathrm{C}} 157.5(\mathrm{C}-5), 27.2(\mathrm{C}-2)$, and $143.1(\mathrm{C}-8 \mathrm{a})$. The ${ }^{1} \mathrm{H}$ and ${ }^{13} \mathrm{C}$ NMR spectra of 2 were very similar to those of nodulisporol [12]. The main difference between $\mathbf{2}$ and nodulisporol was the replacement of a hydroxyl group with a methoxy group at $\mathrm{C}-4$.

Table 2. ${ }^{1} \mathrm{H}$ and ${ }^{13} \mathrm{C}$ NMR (DMSO- $d_{6}, 600$ and $150 \mathrm{MHz}$ ) and COSY and HMBC assignment of 2.

\begin{tabular}{ccccc}
\hline Position & $\delta_{\mathrm{C}}$, Type & $\delta_{\mathrm{H}}$ (Mult., $\boldsymbol{J}$ in Hz) & COSY & HMBC \\
\hline 1 & $67.8, \mathrm{CH}$ & $4.41, \mathrm{~m}$ & $\mathrm{H}-2$ & $\mathrm{C}-3,8,8 \mathrm{a}$ \\
2 & $27.2, \mathrm{CH}_{2}$ & $1.80, \mathrm{~m}$ & $\mathrm{H}-1,3$ & \\
$3 \alpha$ & $24.7, \mathrm{CH}_{2}$ & $2.09, \mathrm{~m}$ & $\mathrm{H}-2,4$ & $\mathrm{C}-4 \mathrm{a}$ \\
$3 \beta$ & $69.8, \mathrm{CH}$ & $4.35, \mathrm{t}(2.8)$ & $\mathrm{H}-3$ & $\mathrm{C}-2,5,8 \mathrm{a}$ \\
4 & $124.8, \mathrm{C}$ & & & \\
$4 \mathrm{a}$ & $157.5, \mathrm{C}$ & & & \\
5 & $128.5, \mathrm{CH}$ & $7.24, \mathrm{~d}(7.9)$ & $\mathrm{H}-7$ & $\mathrm{C}-4 \mathrm{a}, 5$ \\
6 & $108.8, \mathrm{CH}$ & $6.83, \mathrm{~d}(8.1)$ & $\mathrm{H}-6,8$ & $\mathrm{C}-8 \mathrm{a}$ \\
7 & $118.7, \mathrm{CH}$ & $7.14, \mathrm{~d}(7.7)$ & $\mathrm{H}-7$ & \\
8 & $143.1, \mathrm{C}$ & & & \\
$8 \mathrm{a}$ & $5.28, \mathrm{~s}$ & & $\mathrm{C}-4$ \\
$1-\mathrm{OH}$ & $56.7, \mathrm{CH}_{3}$ & $3.31, \mathrm{~s}$ & & $\mathrm{C}-5$ \\
$4-\mathrm{OCH}_{3}$ & $55.7, \mathrm{CH}_{3}$ & $3.75, \mathrm{~s}$ & & \\
$5-\mathrm{OCH}_{3}$ & & & &
\end{tabular}


The relative configuration of 2 was determined from its NOESY spectrum, which showed correlations from $\mathrm{H}-1 / \mathrm{H}-3 \alpha\left(\delta_{\mathrm{H}} 2.09\right)$, and $\mathrm{H}-4 / \mathrm{H}-3 \beta\left(\delta_{\mathrm{H}} 1.51\right)$ suggesting that $\mathrm{H}-1$ and $\mathrm{H}-4$ were on the opposite face. To establish the absolute configuration of $\mathrm{C}-1$ and C-4, the ECD spectra of two simplified isomers $(1 S 4 S$, and $1 R 4 R)$ of 2 were calculated at the Cam-B3LYP/6-31+G(d,p) level of theory in methanol, and these calculated spectra were compared with the experimental spectrum of $\mathbf{2}$. The experimental ECD spectrum of 2 showed an excellent fit with the calculated ECD spectrum of $1 S 4 S-2$ (Figure 4), establishing the absolute configurations of C-1 and C-4 as $1 S 4 S$. Since 2 has never been reported, it was named guhypoxylonol B.

Compound (3) was obtained as a colorless powder with a molecular formula of $\mathrm{C}_{13} \mathrm{H}_{18} \mathrm{O}_{3}$ as deduced from the HRESIMS $m / z 223.1332[\mathrm{M}+\mathrm{H}]^{+}$(cald 223.1334 for $\mathrm{C}_{13} \mathrm{H}_{19} \mathrm{O}_{3}$ ), indicating five degrees of unsaturation. The ${ }^{1} \mathrm{H}$ NMR (Table 3), in combination with DEPT and HSQC spectra, displayed two doublets of methylene group at $\delta_{\mathrm{H}}$ $4.65(J=15.8 \mathrm{~Hz}, \mathrm{H}-8)$ and $4.58(\mathrm{~J}=15.8 \mathrm{~Hz}, \mathrm{H}-8)$, two multiplets of methine groups at $\delta_{\mathrm{H}} 3.86(\mathrm{~J}=6.6,2.6 \mathrm{~Hz}, \mathrm{H}-2)$ and $2.63(\mathrm{~J}=6.8,2.6 \mathrm{~Hz}, \mathrm{H}-3)$, two methyl doublets at $\delta_{\mathrm{H}}$ $1.18(J=6.8 \mathrm{~Hz}, \mathrm{H}-11)$ and $\delta_{\mathrm{H}} 1.19(J=6.6 \mathrm{~Hz}, \mathrm{H}-12)$, and two methyl singlets at $\delta_{\mathrm{H}} 2.10$ (H-9, H-10). The ${ }^{13} \mathrm{C}$ NMR (Table 3) spectrum, in combination with HMQC spectrum, of 3 revealed the presence of four methyl carbons at $\delta_{C} 21.0,18.2,9.1$, and 11.1, one $\mathrm{sp}^{3}$ methylene carbon at $\delta_{\mathrm{C}} 60.8$, two sp ${ }^{3}$ methine carbons at $\delta_{\mathrm{C}} 76.0$ and 36.4, together with six non-protonated $\mathrm{sp}^{2}$ carbons at $\delta_{\mathrm{C}} 153.3,149.6,134.8,115.9,114.4$, and 111.3. The COSY (Figure 2) correlations from $\mathrm{H}-2$ to $\mathrm{H}-3$ and $\mathrm{H}_{3}-11$, and $\mathrm{H}-3$ to $\mathrm{H}_{3}-12$ suggest the existence of $-\mathrm{CH}\left(\mathrm{CH}_{3}\right) \mathrm{CH}\left(\mathrm{CH}_{3}\right) \mathrm{O}$-. The HMBC (Figure 2) correlations from H-2 to $\delta_{\mathrm{C}} 21.0(\mathrm{C}-11)$, 134.8 (C-3a), 36.4 (C-3), and 60.8 (C-8), from H-3 to $\delta_{\mathrm{C}} 134.8$ (C-3a), 115.9 (C-4), 114.4 (C-7a), $18.2(\mathrm{C}-12)$, and $21.0(\mathrm{C}-11)$, suggests that $\mathrm{C}-3$ is connected to $\mathrm{C}-3 \mathrm{a}$. The HMBC correlations from $\mathrm{H}-9\left(\delta_{\mathrm{H}} 2.10\right)$ to $\mathrm{C}-4, \mathrm{C}-5\left(\delta_{\mathrm{C}} 111.3\right)$, and C-3a, from H-10 $\left(\delta_{\mathrm{H}} 2.10\right)$ to C-4, C-5, C-6 $\left(\delta_{\mathrm{C}}\right.$ 153.3), indicate that the two methyl groups were on $\mathrm{C}-4$ and $\mathrm{C}-5$, respectively. Finally, the HMBC correlations from H-8 to C-3a, C-7a, C-2 $\left(\delta_{\mathrm{C}} 76.0\right)$, and C-7 $\left(\delta_{\mathrm{C}} 149.6\right)$, indicated that the remaining substructure of 3 was established as shown in Figure 1.

A NOSEY correlation observed between $\mathrm{H}-2$ and $\mathrm{H}-3$, suggests that the relative configuration of 3 is either $2 R^{*} 3 R^{*}$ or $2 S^{*} 3 S^{*}$ (Figure 3). The absolute configurations of $C-2$ and C-3 were established by comparing the experimental and calculated ECD spectra of $2 R 3 R$, and $2 S 3 S$. The experimental ECD spectrum of 3 matched very well with the calculated 2S3S-3 ECD spectrum (Figure 4), calculated at the Cam-B3LYP/6-311+G (2d,p) level of theory in methanol. Therefore, the absolute configurations of C-2 and C-3 were determined to be $2 S 3 S$. Since 3 has never been reported, it was named guhypoxylonol C.

Table 3. ${ }^{1} \mathrm{H}$ and ${ }^{13} \mathrm{C}$ NMR $\left(\mathrm{CD}_{3} \mathrm{OD}, 400\right.$ and $\left.100 \mathrm{MHz}\right)$ and COSY and HMBC assignment of 3.

\begin{tabular}{ccccc}
\hline Position & $\delta_{\mathbf{C}}$, Type & $\delta_{\mathbf{H}}$ (Mult., J in Hz) & COSY & HMBC \\
\hline 2 & $76.0, \mathrm{CH}$ & 3.86, qd $(6.6,2.6)$ & $\mathrm{H}-3,11$ & $\mathrm{C}-3,3 \mathrm{a}, 8,12$ \\
3 & $36.4, \mathrm{CH}$ & $2.63, \mathrm{qd}(6.8,2.6)$ & $\mathrm{C}-3 \mathrm{a}, 4,7 \mathrm{a}, 11,12$ & 12 \\
$3 \mathrm{a}$ & $134,8, \mathrm{C}$ & & \\
4 & $115.9, \mathrm{C}$ & & \\
5 & $111.3, \mathrm{C}$ & & \\
6 & $153.3, \mathrm{C}$ & & \\
7 & $149.6, \mathrm{C}$ & & $\mathrm{C}-2,3 \mathrm{a}, 7,7 \mathrm{a}$ \\
$7 \mathrm{a}$ & $114.4, \mathrm{C}$ & & $\mathrm{C}-3 \mathrm{a}, 4,5$ \\
8 & $60.8, \mathrm{CH}_{2}$ & $4.65, \mathrm{~d}(15.2)$ & $\mathrm{C}-4,5,6$ \\
9 & $11.1, \mathrm{CH}_{3}$ & $4.58, \mathrm{~d}(15.2)$ & \\
10 & $9.1, \mathrm{CH}_{3}$ & $2.10, \mathrm{~s}$ & \\
11 & $21.0, \mathrm{CH}_{3}$ & $2.10, \mathrm{~s}$ & \\
\end{tabular}


Compound (4) was obtained as a white powder and the molecular formula $\mathrm{C}_{25} \mathrm{H}_{30} \mathrm{O}_{9}$ was deduced from the HRESIMS $m / z 473.1816[\mathrm{M}-\mathrm{H}]^{-}$(cald 473.1812 for $\mathrm{C}_{25} \mathrm{H}_{29} \mathrm{O}_{9}$ ), indicating 11 degrees of unsaturation. The ${ }^{1} \mathrm{H}$ NMR (Table 4) spectrum of 4 displayed two methyl singlets at $\delta_{\mathrm{H}} 2.10(\mathrm{H}-9)$ and $2.07(\mathrm{H}-10)$, one methoxyl singlet at $\delta_{\mathrm{H}} 3.67\left(-\mathrm{OCH}_{3}-8\right)$, and two singlets at $\delta_{\mathrm{H}} 3.73\left(\mathrm{H}_{2}-7\right)$ and $2.50\left(\mathrm{H}_{2}-11\right)$. The ${ }^{13} \mathrm{C}$ NMR spectrum (Table 4$)$, in combination with the HSQC spectrum of 4, displayed one ketone carbonyl at $\delta_{\mathrm{C}} 207.9$ (C-12), one ester carbonyl at $\delta_{\mathrm{C}} 173.8(\mathrm{C}-8)$, one methoxy at $\delta_{\mathrm{C}} 52.5\left(\mathrm{OCH}_{3}\right)$, two methyls at $\delta_{\mathrm{C}} 12.1$, and 9.0, and the two $\mathrm{sp}^{3}$ methylene carbons at $\delta_{\mathrm{C}} 36.5$ (C-7) and 32.5 (C-11). The presence of six non-protonated $\mathrm{sp}^{2}$ at $\delta_{\mathrm{C}} 123.1,118.7,155.3,112.5,157.5$, and 130.6 is an indicative of the presence of a benzene ring. The HMBC correlations (Figure 2) from $\delta_{\mathrm{H}}$ $3.73(\mathrm{H}-7)$ to $\mathrm{C}-8,123.1(\mathrm{C}-6), 118.7(\mathrm{C}-1)$, and from $\delta_{\mathrm{H}} 3.67$ to $\mathrm{C}-8$, confirm that a methyl acetate is connected to $\mathrm{C}-1$. HMBC correlations from $\delta_{\mathrm{H}} 2.07$ (H-9) to C-1, $130.6(\mathrm{C}-2)$, and $157.5(\mathrm{C}-3)$, from $\delta_{\mathrm{H}} 2.07$ (H-10) to $\delta_{\mathrm{C}} 112.5$ (C-4), 155.3 (C-5), and C-3, and from H-11 to C-1 and $\mathrm{C}-12$, suggested that 4 contains methyl (3,5-dihydroxy-2,4-dimethyl pheny) acetate moiety, with $-\mathrm{CH}_{2}-\mathrm{C}=\mathrm{O}$ connected to $\mathrm{C}-6$. Since the molecular formula of $\mathrm{C}_{25} \mathrm{H}_{30} \mathrm{O}_{9}$, only a ketone carbonyl $\left(\delta_{\mathrm{C}} 207.9\right)$ is present in 4 . Therefore, the structure of 4 is a disubstituted acetone whose substituents are methyl (3,5-digydroxy-2,4-dimethylphenyl)acetate. Since 4 has never been reported, it was named guhypoxylonol $\mathrm{D}$.

Table 4. ${ }^{1} \mathrm{H}$ and ${ }^{13} \mathrm{C}$ NMR $\left(\mathrm{CD}_{3} \mathrm{OD}, 400\right.$ and $\left.100 \mathrm{MHz}\right)$ and $\mathrm{HMBC}$ assignment of 4.

\begin{tabular}{cccc}
\hline Position & $\delta_{\mathrm{C}}$, Type & $\delta_{\mathbf{H}}$ (Mult., $\boldsymbol{J}$ in Hz) & HMBC \\
\hline $1\left(1^{\prime}\right)$ & $118.7, \mathrm{C}$ & & \\
$2\left(2^{\prime}\right)$ & $130.6, \mathrm{C}$ & & \\
$3\left(3^{\prime}\right)$ & $157.5, \mathrm{C}$ & & \\
$4\left(4^{\prime}\right)$ & $112.5, \mathrm{C}$ & & \\
$5\left(5^{\prime}\right)$ & $155.3, \mathrm{C}$ & & \\
$6\left(6^{\prime}\right)$ & $123.6, \mathrm{C}$ & & \\
$7\left(7^{\prime}\right)$ & $36.5, \mathrm{CH}_{2}$ & $3.73, \mathrm{~s}$ & \\
$8\left(8^{\prime}\right)$ & $173.8, \mathrm{C}$ & & \\
$9\left(9^{\prime}\right)$ & $\left.9.0, \mathrm{CH}_{3}\right), 6\left(6^{\prime}\right), 8\left(8^{\prime}\right)$ \\
$10\left(10^{\prime}\right)$ & $12.1, \mathrm{CH}_{3}$ & $2.10, \mathrm{~s}$ & $\mathrm{C}-1\left(1^{\prime}\right), 2\left(2^{\prime}\right), 3\left(3^{\prime}\right)$ \\
$11\left(11^{\prime}\right)$ & $32.5, \mathrm{CH}_{2}$ & $2.07, \mathrm{~s}$ & $\mathrm{C}-3\left(3^{\prime}\right), 4\left(4^{\prime}\right), 5\left(5^{\prime}\right)$ \\
12 & $207.9, \mathrm{C}$ & $2.50, \mathrm{~s}$ & $\mathrm{C}-1\left(1^{\prime}\right), 12$ \\
$8-\mathrm{OCH}_{3}$ & $52.5, \mathrm{CH}_{3}$ & & $\mathrm{C}-8\left(8^{\prime}\right)$ \\
\hline
\end{tabular}

The previously described 5-11 were identified based on the analysis of their NMR data, and compared with those reported in the literature and identified as hypoxylonol C (5) [11], hypoxylonol B (6) [11], daldinone C (7) [13], nodulisporol (8) [12], isosclerone (9) [14], xylarenone (10) [14], scytalone (11) [15], respectively.

\subsection{Anti-Inflammatory Activity}

Compounds 1-11 were evaluated for their anti-inflammatory effects on the production of the NO in the RAW 264.7 macrophage cell line exposed to the inflammatory stimulus by lipopolysaccharide (LPS) (Table 5). Compounds 1, 3, 4, and $\mathbf{6}$ showed inhibitory activity against the production of $\mathrm{NO}$, with the $\mathrm{IC}_{50}$ values $14.42 \pm 0.11,18.03 \pm 0.14,16.66 \pm 0.21$, and $21.05 \pm 0.13 \mu \mathrm{M}$, respectively. Dexamethasone was used as a positive control with $\mathrm{IC}_{50}$ value of $16.12 \pm 1.41 \mu \mathrm{M}$, while $\mathbf{2 , 5}$, and 7-11 did not show any inhibitory activity under their safe concentrations. 
Table 5. Inhibitory activities of $\mathbf{1 - 1 1}$ on NO production in LPS-induced RAW 264.7 cells ${ }^{\text {a }}$.

\begin{tabular}{cc}
\hline Compounds & IC $_{\mathbf{5 0}}(\boldsymbol{\mu M})$ \\
\hline $\mathbf{1}$ & $14.42 \pm 0.11$ \\
$\mathbf{2}$ & $32.48 \pm 0.19$ \\
$\mathbf{3}$ & $18.03 \pm 0.14$ \\
$\mathbf{4}$ & $16.66 \pm 0.21$ \\
$\mathbf{5}$ & $>80$ \\
$\mathbf{6}$ & $21.05 \pm 0.13$ \\
$\mathbf{7}$ & $>80$ \\
$\mathbf{8}$ & $>80$ \\
$\mathbf{9}$ & $>80$ \\
$\mathbf{1 0}$ & $>80$ \\
$\mathbf{1 1}$ & $>80$ \\
Dexamethasone $^{\mathrm{b}}$ & $16.12 \pm 1.41 \mu \mathrm{M}$
\end{tabular}

a Values present mean \pm SD of triplicate experiments. ${ }^{b}$ Dexamethasone was used as a positive control.

\section{Materials and Methods}

\subsection{General Experimental Procedures}

NMR spectra were recorded on a AVANCE-400 spectrometer (Bruker, Bremen, Germany). The chemical shifts of ${ }^{1} \mathrm{H}$ and ${ }^{13} \mathrm{C}$ NMR spectra are given in $\delta(\mathrm{ppm})$ and referenced to the solvent signal (DMSO- $d_{6}, \delta_{\mathrm{H}} 2.50$ and $\delta_{\mathrm{C}} 39.52, \mathrm{CD}_{3} \mathrm{OD}-d_{4}, \delta_{\mathrm{H}} 3.34$ and $\delta_{\mathrm{C}} 49.00$ ). Coupling constants $(J)$ are reported in Hz. The mass spectrometric (HRESIMS) data were acquired using a Micro Mass Q-TOF spectrometer (Waters Corporation, Milford, MA, USA). ECD data was recorded using a JASCO J-715 spectropolarimeter (Jasco, Tokyo, Japan). Semipreparative HPLC was performed on an ODS column $(10 \times 250 \mathrm{~mm}, 5 \mu \mathrm{m}, 3 \mathrm{~mL} / \mathrm{min}$, YMC, Kyoto, Japan).

\subsection{Fungal Material}

The strain GXNU-Y45 was isolated from a leaf of a mangrove tree Acanthus ilicifolius, October 2019, in Beihai City, China. The fungal strain GXNU-Y45 was identified as Aspergillus sp. based on the sequence of its internal transcribed spacer region (ITS) and morphology. ITS-rDNA of GXNU-Y45 was submitted to GenBank and the accession number is MT626059.

\subsection{Fermentation, Extraction, and Isolation}

The fungus was cultured in $60 \times 1000 \mathrm{~mL}$ Erlenmeyer flasks each containing $50 \mathrm{~g}$ cooked rice and $60 \mathrm{~mL}$ of water (30 g sea salt, per liter pure water) or $300 \mathrm{~mL}$ medium (liquid media, $20.0 \mathrm{~g}$ dextrose, $20.0 \mathrm{~g}$ potatoes, $30 \mathrm{~g}$ sea salt, per liter pure water). The fungus was cultured in the medium and incubated at room temperature for 35 days.

\subsection{Extraction and Isolation}

The fermented material was extracted three times with EtOAc to obtain $16.8 \mathrm{~g}$ crude extract (liquid medium) and $20.2 \mathrm{~g}$ (solid medium). The crude extract was subjected to a silica gel VLC column, eluting with a stepwise gradient of petroleum ether-EtOAc $(10: 1,8: 1$, 6:1, 4:1, 2:1, 1:1, v/v) to yield six subfractions (Fr. 1-Fr. 6). Fr. $3(3 \mathrm{~g})$ was applied to ODS silica gel with gradient elution of $\mathrm{MeOH}-\mathrm{H}_{2} \mathrm{O}(3: 7,4: 6,5: 5,6: 4,7: 3,9: 1,0: 1, v / v)$ to afford four subfractions (Fr. 3-1-Fr. 3-4). Fr. 3-2 (650 mg) was subjected to semipreparative HPLC $\left(70 \% \mathrm{MeOH} / \mathrm{H}_{2} \mathrm{O} ; 3 \mathrm{~mL} / \mathrm{min}\right)$ to obtain $1(15.6 \mathrm{mg}), 2(7.5 \mathrm{mg})$, and $3(4.4 \mathrm{mg})$. Fr. 3-3 (345 mg) was repurified by RP-18 CC (eluted with $\mathrm{MeOH} / \mathrm{H}_{2} \mathrm{O}$ from 3:7 to 10:0, $v / v$ ) and Sephadex LH-20 (eluted with $\left.\mathrm{CH}_{2} \mathrm{Cl}_{2} / \mathrm{MeOH}, 5: 5, v / v\right)$ to afford 5 (10.6 mg), 9 (3.3 mg), 10 $(5.2 \mathrm{mg})$, and $\mathbf{1 1}(6.7 \mathrm{mg})$. Fr. $4(1.1 \mathrm{~g})$ was separated by ODS silica gel with gradient elution of $\mathrm{MeOH}-\mathrm{H}_{2} \mathrm{O}(1: 9,2: 8,3: 7,4: 6,5: 5,6: 4,7: 3,9: 1,0: 1, v / v)$ to yield four subfractions (Fr. 4-1-Fr. 4-4). Fr.4-3 (73 mg) was purified by Sephadex LH-20 eluted with $\mathrm{CH}_{2} \mathrm{Cl}_{2} / \mathrm{MeOH}$ (50:50) to give $4(6.3 \mathrm{mg})$. Fr.4-4 $(84 \mathrm{mg})$ was separated by semipreparative HPLC $(80 \%$ $\left.\mathrm{MeCN} / \mathrm{H}_{2} \mathrm{O} ; 3 \mathrm{~mL} / \mathrm{min}\right)$ to give $6(5.6 \mathrm{mg}), 7(8.1 \mathrm{mg})$, and $8(5.2 \mathrm{mg})$. 
Guhypoxylonol A (1): was obtained as a brown oil; $[\alpha]_{D}^{20}+63.2(\mathrm{c} 0.6, \mathrm{MeOH}) ;{ }^{1} \mathrm{H}$ and ${ }^{13} \mathrm{C}$ NMR data (see Tables 1 and 2); HRESIMS $m / z 389.1004\left([\mathrm{M}+\mathrm{Na}]^{+}\right.$(cald $\mathrm{C}_{21} \mathrm{H}_{18} \mathrm{O}_{6} \mathrm{Na}$, 389.1001).

Guhypoxylonol B (2): was obtained as a colorless powder; $[\alpha]_{D}^{20}+8.5(\mathrm{c} 0.6, \mathrm{MeOH}) ;{ }^{1} \mathrm{H}$ and ${ }^{13} \mathrm{C}$ NMR data (see Tables 1 and 2); HRESIMS $m / z 231.0998[\mathrm{M}+\mathrm{Na}]^{+}$(cald 231.0997 for $\mathrm{C}_{12} \mathrm{H}_{16} \mathrm{O}_{3} \mathrm{Na}$ ).

Guhypoxylonol C (3): white powder; $[\alpha]_{D}^{20}+80(\mathrm{c} 0.6, \mathrm{MeOH}) ;{ }^{1} \mathrm{H}$ and ${ }^{13} \mathrm{C} \mathrm{NMR}$ data (see Tables 1 and 2); HRESIMS $m / z 223.1332[\mathrm{M}+\mathrm{H}]^{+}$(cald 223.1334 for $\mathrm{C}_{13} \mathrm{H}_{19} \mathrm{O}_{3}$ ).

Guhypoxylonol D (4): white powder; ${ }^{1} \mathrm{H}$ and ${ }^{13} \mathrm{C}$ NMR data (see Tables 1 and 2); HRESIMS $m / z 473.1816[\mathrm{M}-\mathrm{H}]^{-}$(cald 473.1812 for $\mathrm{C}_{25} \mathrm{H}_{30} \mathrm{O}_{9}$ ).

\subsection{Anti-Inflammatory Assay}

The anti-inflammatory effects of compounds 1-11 were examined on the production of the NO in LPS-stimulated cells using a method described in the literature [16].

\section{Conclusions}

The chemical investigation of a marine-derived fungus Aspergillus sp. GXNU-Y45 resulted in the isolation of four undescribed compounds (1-4), and seven previously reported metabolites (5-11). Based on modifications of the culture medium strategy, the fungus Aspergillus sp. GXNU-Y45 was cultured in different media to stimulate a production of its metabolites. It was found that the fungus Aspergillus sp. GXNU-Y45 produced different metabolites in two culture media. The liquid medium can stimulate the fungus to produce a series of metabolites, $\mathbf{1}, 5,6,7,8,9,10$, and 2 (a new precursor of $\mathbf{1}$ ). On the contrary the solid medium yeiled 3 and 4 . Different compositions of the culture media represented a powerful tool to induce new metabolites from microorganisms. Preliminarily screening of 1-11 for their ability to prevent NO production of LPS-induced RAW264.7 cells showed that 1, 3, 4, and 6 exhibited significant inhibitory effects against NO release with $\mathrm{IC}_{50}$ values of $14.42 \pm 0.11,18.03 \pm 0.14,16.66 \pm 0.21$, and $21.05 \pm 0.13 \mu \mathrm{M}$, respectively. The inhibition of NO production by 1 and 6 was stronger than 5 and 7, which showed the same skeleton but differ only the presence of $-\mathrm{OCH}_{3}$ at $\mathrm{C}-3$. Compounds $\mathbf{2}$ and 8-11, which are precursors of $\mathbf{1}, 5,6$, and 7 , did not exhibit inhibitory effects against NO release. Compounds 3 and 4 exhibited remarkable inhibitory effects against NO release suggesting that the fully substituted benzene ring was essential for inhibition of the production of $\mathrm{NO}$ release. In summary, this study revealed that 1, 3, 4, and 6 could be considered as potential metabolites for further anti-inflammatory studies.

Supplementary Materials: The following are available online at https:/ / www.mdpi.com/article / 10.3390/md20010005/s1, NMR and HRESIMS spectra of 1-11.

Author Contributions: R.Y. and X.H. conceived and designed the experiments. X.Q. performed the experiments. J.H., W.Z., D.Z., Y.Z., J.L. and X.H. analyzed the data. X.Q. and X.H. wrote the paper. All authors have read and agreed to the published version of the manuscript.

Funding: The authors (R.Y. and X.H.) acknowledge the following agencies for funding this project: National Natural Science Foundation of China (21662004, 42066005, 21762007); the Natural Science Foundation of Guangxi Province (2020JJA150036); the Open Research Fund Program of the Key Laboratory for the Chemistry and Molecular Engineering of Medicinal Resources (CMEMR2019-A1); Guangxi Science and Technology Base Special Talents (2019AC20095); the Guangdong Educational Committee (2018GkQNCX029, 2020WQYB042, 2018GKTSCX072); Foundation for University Key Teacher by the Guangdong Industry Poytechnic (KYRC2019-11).

Institutional Review Board Statement: Not applicable.

Informed Consent Statement: Not applicable.

Data Availability Statement: The authors declare that all data of this study are available within the article and its Supplementary Materials file or from the corresponding authors upon request.

Conflicts of Interest: The authors declare no conflict of interest. 


\section{References}

1. Carroll, A.; Copp, B.; Davis, R.A.; Keyzers, R.A.; Prinsep, M.R. Marine natural products. Nat. Prod. Rep. 2020, $37,175-223$. [CrossRef]

2. Hu, Y.; Chen, J.; Hu, G.; Yu, J.; Zhu, X.; Lin, Y.; Chen, S.; Yuan, J. Statistical Research on the Bioactivity of New Marine Natural Products Discovered during the 28 Years from 1985 to 2012. Mar. Drugs 2015, 13, 202-221. [CrossRef]

3. Cao, F.; Meng, Z.-H.; Wang, P.; Luo, D.-Q.; Zhu, H.-J. Dipleosporalones A and B, Dimeric Azaphilones from a Marine-Derived Pleosporales sp. Fungus. J. Nat. Prod. 2020, 83, 1283-1287. [CrossRef]

4. Carroll, A.; Copp, B.; Davis, R.; Keyzers, R.A.; Prinsep, M.R. Marine natural products. Nat. Prod. Rep. 2019, 36, 112-173. [CrossRef]

5. Dai, L.-T.; Yang, L.; Kong, F.-D.; Ma, Q.-Y.; Xie, Q.-Y.; Dai, H.-F.; Yu, Z.-F.; Zhao, Y.-X. Cytotoxic Indole-Diterpenoids from the Marine-Derived Fungus Penicillium sp. KFD28. Mar. Drugs 2021, 19, 613. [CrossRef] [PubMed]

6. Ryu, M.-J.; Hillman, P.F.; Lee, J.; Hwang, S.; Lee, E.-Y.; Cha, S.-S.; Yang, I.; Oh, D.-C.; Nam, S.-J.; Fenical, W. Antibacterial Meroterpenoids, Merochlorins G-J from the Marine Bacterium Streptomyces sp. Mar. Drugs 2021, 19, 618. [CrossRef] [PubMed]

7. Cui, H.; Lin, Y.; Luo, M.; Lu, Y.; Huang, X.; She, Z. Diaporisoindoles A-C: Three Isoprenylisoindole Alkaloid Derivatives from the Mangrove Endophytic Fungus Diaporthe sp. SYSU-HQ3. Org. Lett. 2017, 19, 5621-5624. [CrossRef] [PubMed]

8. Cui, H.; Liu, Y.; Li, J.; Huang, X.; Yan, T.; Cao, W.; Liu, H.; Long, Y.; She, Z. Diaporindenes A-D: Four Unusual 2,3-Dihydro-1Hindene Analogues with Anti-inflammatory Activities from the Mangrove Endophytic Fungus Diaporthe sp. SYSU-HQ3. J. Org. Chem. 2018, 83, 11804-11813. [CrossRef] [PubMed]

9. Chen, S.; Ding, M.; Liu, W.; Huang, X.; Liu, Z.; Lu, Y.; Liu, H.; She, Z. Anti-inflammatory meroterpenoids from the mangrove endophytic fungus Talaromyces amestolkiae YX1. Phytochemistry 2018, 146, 8-15. [CrossRef] [PubMed]

10. Cui, H.; Liu, Y.; Nie, Y.; Liu, Z.; Chen, S.; Zhang, Z.; Lu, Y.; He, L.; Huang, X.; She, Z. Polyketides from the Mangrove-Derived Endophytic Fungus Nectria sp. HN001 and Their $\alpha$-Glucosidase Inhibitory Activity. Mar. Drugs 2016, 14, 86. [CrossRef] [PubMed]

11. Fukai, M.; Tsukada, M.; Miki, K.; Suzuki, T.; Sugita, T.; Kinoshita, K.; Takahashi, K.; Shiro, M.; Koyama, K. Hypoxylonols C-F, Benzo[j]fluoranthenes from Hypoxylon truncatum. J. Nat. Prod. 2011, 75, 22-25. [CrossRef] [PubMed]

12. Kamisuki, S.; Ishimaru, C.; Onoda, K.; Kuriyama, I.; Ida, N.; Sugawara, F.; Yoshidab, H.; Mizushina, Y. Nodulisporol and nodulisporone, novel specific inhibitors of human DNA polymerase $\mathrm{k}$ from a fungus, Nodulisporium sp. Bioorg. Med. Chem. 2007, 15, 3109-3114. [CrossRef] [PubMed]

13. Gu, W.; Ge, H.M.; Song, Y.C.; Ding, H.; Zhu, H.L.; Zhao, A.X.A.; Tan, R.X. Cytotoxic Benzo[j]fluoranthene Metabolites from Hypoxylon truncatum IFB-18, an Endophyte of Artemisia annua. J. Nat. Prod. 2007, 70, 114-117. [CrossRef] [PubMed]

14. Yang, N.N.; Ma, Q.Y.; Kong, F.D.; Xie, Q.Y.; Dai, H.F.; Zhou, L.M.; Yu, Z.F.; Zhao, Y.X. Napthrene Compounds from Mycelial Fermentation Products of Marasmius berteroi. Molecules 2020, 25, 3898. [CrossRef] [PubMed]

15. Sone, Y.; Nakamura, S.; Sasaki, M.; Hasebe, F.; Kim, S.-Y.; Funa, N. Bacterial Enzymes Catalyzing the Synthesis of 1,8Dihydroxynaphthalene, a Key Precursor of Dihydroxynaphthalene Melanin, from Sorangium cellulosum. Appl. Environ. Microbiol. 2018, 84, e00258-18. [CrossRef] [PubMed]

16. Liu, W.; Deng, S.; Zhou, D.; Huang, Y.; Li, C.; Hao, L.; Zhang, G.; Su, S.; Xu, X.; Yang, R.-Y.; et al. 3,4-seco-Dammarane Triterpenoid Saponins with Anti-Inflammatory Activity Isolated from the Leaves of Cyclocarya paliurus. J. Agric. Food Chem. 2020, 68, 2041-2053. [CrossRef] [PubMed] 